Теоретико-практичні проблеми педагогіки вищої школи

УДК $371.124: 54$

\author{
Анатолій Кузьмінський, \\ Ніна Тарасенкова, Ірина Акуленко
}

\title{
ІННОВАЦІЇ В МЕТОДОЛОГІЇ МЕТОДИЧНОЇ ПІДГОТОВКИ МАЙБУТНЬОГО ВЧИТЕЛЯ МАТЕМАТИКИ ПРОФІЛЬНОӤ ШКОЛИ
}

Кузьмінський А. І., Тарасенкова Н. А., Акуленко І. А. Інновації в методології методичної підготовки майбутнього вчителя математики профільної школи.

У статті обгрунтовано необхідність звернення до методології діатропічного підходу, схарактеризовано сутність діатропічних процедур і проілюстровано їх утілення в конструюванні змісту методичної підготовки майбутнього вчителя математики профільної школи.

Ключові слова: діатропічний підхід, діатропічний аналіз, методична підготовка майбутнього вчителя математики профільної школи.

Кузьминский А. И., Тарасенкова Н. А., Акуленко И. А. Инновации в методологии методической подготовки будущего учителя математики профильной школы.

В статье обоснована необходимость обращения к методологии диатропического подхода, раскрыта сущность диатропических процедур, проиллюстрировано их воплощение в конструировании содержания методической подготовки будущего учителя математики профильной школы.

Ключевые слова: диатропический подход, диатропический анализ, методическая подготовка будущего учителя математики профильной школы.

Kuzminskii A. I., Tarasenkova N. A., Akulenko I. A. Innovations in methodical training of future mathematics teacher profile school methodology.

The paper considers the needness to turn to the diatropic approach methodology, reveals the essence diatropic procedures, illustrates their objectification in the content of future math teacher's of profile school methodical training.

Key words: diatropic approach, diatropic analysis, future mathematics teachers' of profile school methodical preparation.

Сучасні процеси у вітчизняному освітньому просторі, які характеризують як процеси утвердження нової соціально-особистісно зорієнтованої освітньої парадигми (О. Морева $[0])$, індукують зміни у середній і вищій школі. У першому випадку їх виявом $\epsilon$ упровадження профільної диференціації у старшу ланку загальної середньої освіти, у другому - актуалізація проблеми соціалізації молодого покоління в період навчання у ВН3. Відповідно, природнім $є$ звернення в теорії навчання й освітянській практиці до компетентнісного підходу, який $\epsilon$ важливим як для математичної підготовки старшокласників в умовах профільного навчання, так і для методичної підготовки майбутніх учителів математики, які реалізуватимуть це навчання.

Навчаючи математики у старшій профільній школі, учителі мають бути готовими до розв'язання низки принципово нових завдань. Найголовнішим 3-поміж інших є варіювання методичних систем навчання залежно від профілю.

Водночас аналіз сучасного стану підготовки майбутнього вчителя, здійснений у дослідженнях Г. Бевза, В. Бевз, М. Бурди, М. Ігнатенка, Н. Кучугової, 
М. Макарченка, В. Моторіної, І. Малової, Н. Подходової, С. Ракова, С. Семерікова, С. Семенця, О. Скафи, С. Скворцової, Н. Стефанової $[2 ; 4 ; 6 ; 7 ; 8 ; 9 ; 10 ; 11 ; 02]$ та ін., свідчить, що студенти й молоді фахівці мають суттєві прогалини у своїй методичній підготовці, наприклад, у знаннях змісту шкільного курсу математики, що вивчається у старшій профільній школі, у застосуванні математичних знань для розв'язування задач практичного спрямування. Молоді фахівці слабко орієнтуються в тому, якими математичними моделями оперують у різних галузях знань. Удосконалення потребує також підготовка студентів щодо реалізації в навчанні математики взаємозв'язків між різними розділами шкільного курсу, між математичним програмовим матеріалом $\mathrm{i}$ тим навчальним змістом, який опановують учні під час вивчення профільних дисциплін. Майбутні фахівці неспроможні якісно реалізувати планування, проектування варіацій уведення одиниць математичного змісту на різних рівнях навчання у класах різних профілів, прогнозувати математичні помилки учнів, виявляти причини їх появи. Утруднення студентів значно зростають, якщо методичні об'єкти позв'язані 3 навчанням математики у старшій профільній школі.

Отже, постає проблема про внесення коректив до процесу методичної підготовки майбутнього вчителя математики під час навчання у вищому навчальному закладі.

Метою статmі є розгляд можливих шляхів удосконалення чинної системи методичної підготовки майбутнього вчителя до навчання математики учнів старшої профільної школи.

Зауважимо, що результатом методичної підготовки майбутнього вчителя математики профільної школи мають бути не окремі знання, навички та вміння, а спроможність і готовність молодих фахівців до ефективної, продуктивної, самостійної методичної діяльності. Тобто на часі $є$ їі компетентнісне спрямування.

Традиційно методична підготовка майбутнього вчителя математики будується на засадах системного, історико-цивілізаційного, діяльнісного, особистісно зорієнтованого, аксіологічного, контекстного підходів. Однак у такому разі поза увагою залишається варіативність цілей, змісту, методів і прийомів, організаційних форм і засобів навчання, що $є$ характерним для профільної школи. Тому, на наш погляд, до сучасної методології необхідно додатково долучати інші підходи, такі, що зосереджувалися б не лише на виявленні загальних закономірностей, а й відмінностей, особливостей, розмежувань, специфіки досліджуваних об'єктів. Оптимальним задля розв'язання завдань $є$ діатропічний підхід. Його використання зумовлене варіативністю методичних систем навчання математики у класах різних профілів. Це спричинює додаткові труднощі як у роботі вчителя, так і в процесі методичної підготовки майбутнього вчителя математики профільної школи.

Педагогічна діатропіка вивчає педагогічні феномени, зосереджуючись на їхніх відмінностях за виокремленими ознаками. Цей підхід розробляється такими науковцями, як Ю. Чайковський [13], О. Морева [5] та інші.

Основні процедури діатропічного аналізу - це побудова гомологічних рядів, виокремлення ядра й периферії, гомологій та аналогій. Вихідна процедура - це побудова гомологічного ряду, тобто упорядкованої за певною ознакою множини об'єктів. Наприклад, ряд може відображати цілі навчання теми у класах різних профілів або множину понять, які опановують учні у процесі вивчення певної теми, множину задач прикладного змісту, що мотивують уведення нового матеріалу тощо. Наступна процедура - виокремлення ядра (радикала, стабільного складника ряду) і периферії (варіативного, динамічного складника ряду). Важливою 
процедурою діатропічного аналізу є виявлення аналогій (коли різні елементи мають однакове функціональне призначення) та гомологій (коли однаковий матеріал, застосовуючись у різних умовах, зумовлює різні наслідки, має різний кінцевий ефект і різне функціональне призначення).

Об'єктами для виконання діатропічних процедур в умовах компетентнісно зорієнтованої методичної підготовки майбутнього вчителя математики профільної школи є: 1) функції курсу математики у старшій профільній школі, що вивчають на різних рівнях; 2) цілі, завдання, зміст, методи і прийоми, організаційні форми й засоби математичної підготовки учнів у класах різних напрямів; 3) задачі прикладного спрямування та професійної пропедевтики в навчанні математики в класах різних профілів; 4) взаємозв'язки змісту математичної освіти у класах різних профілів 3 математичним апаратом, що використовують різні галузі знань у вивченні відповідних процесів і явищ; 5) взаємозв'язки методів навчання математики з методами навчання профільних дисциплін; 6) психолого-педагогічні передумови засвоєння математичного змісту учнями, які обирають різні профілі навчання, специфіка знаково-символічної діяльності учнів, які навчаються у класах різних профілів.

Застосування діатропічних процедур, зокрема виявлення аналогій, дозволяє студентам, наприклад, з'ясувати, що задачі, що мотивують вивчення поняття визначеного інтеграла, можуть бути різними в класах різного профілю. У класах фізико-математичного профілю мотивувати вивчення цього поняття можливо на основі задачі про визначення шляху, пройденого тілом при нерівномірному русі, та про роботу з переміщення заряду $q$ в електричному полі, створеному зарядом $Q$. У класах природничого напряму - задачі про визначення загальної чисельності популяції та визначення кількості продукту хімічної реакції за відомою іiі швидкістю. У класах економічного профілю - задача про визначення загального обсягу виробництва за відомою продуктивністю праці або загальних витрат чи доходу за граничними витратами чи доходом відповідно.

Процедура встановлення гомологій надає змогу встановити, що одне й те ж математичне поняття може слугувати математичною моделлю для різноманітних процесів залежно від наукової галузі. В економіці- залежність між обсягом надходжень до бюджету й податковою ставкою $Y=a e^{b(x-c)^{2}}$ (крива Лаффера), у біології - процеси новоутворення й розпаду математично можуть бути описані за допомогою залежності $P=P_{0} e^{k t}$, у хімії залежність швидкості реакції від температури виражається формулою $v_{T_{2}}=v_{T_{1}} \gamma^{\frac{T_{2}-T_{1}}{10}}$, де $v_{T_{1}}, v_{T_{2}}$ - швидкості при температурах $T_{1}, T_{2}, \gamma$ - температурний коефіцієнт (правило Вант-Гоффа), у фізиці- формула зменшення інтенсивності акустичного сигналу через процеси поглинання $I_{x}=I_{0} e^{-2 a x}$, у фінансовій математиці- формула складних відсотків, коли відомою є відсоткова ставка $i P=P_{0}(1+i)^{n}$ та сучасна вартість певної суми грошей, коли відомою $є$ відсоткова ставка і $P_{0}=P(1+i)^{-n}$, в актуарній математиці - модель Гомпертца (1825), у якій інтенсивність смертності задається формулою: $\mu_{x}=B e^{\alpha x}$ та модель Мейкхама (1860), згідно 3 якою інтенсивність смертності апроксимовано більш загальною функцією виду $\mu_{x}=A+B e^{\alpha x}$. 
У діатропіці виокремлюють просторові й часові гомологічні ряди. У процесі методичної підготовки майбутнього вчителя математики профільної школи часовий гомологічний ряд, наприклад, може бути утворений для аналізу педагогічних систем упровадження профільної освіти на території України в різні історичні часи, а просторовий гомологічний ряд - із моделей профілізації освіти в різних країнах: Росії, Україні, Німеччині, США. Зразок побудови таких рядів доцільно спочатку здійснювати викладачеві, наприклад, під час лекції на тему «Окремі аспекти теорії та практики профільної диференціації навчання математики в старшій школі». У подальшому навчанні студентів важливо скеровувати на побудову гомологічних рядів із методичних об'єктів.

Застосування діатропічних процедур уможливлює виявити чинники, що спричинюють варіації методів навчання математики залежно від профілю, а саме: специфічні психофізіологічні особливості школярів, які обирають різні профілі навчання (специфіка способів кодування інформації, домінування певних підструктур математичного мислення тощо), варіації цілей i змісту навчання математики, особливості методів пізнання, що характерні для профільних дисциплін, особливості методів навчання профільних дисциплін.

Студенти в результаті діатропічного аналізу доходять висновку, що у класах суспільно-гуманітарного напряму вчителю краще використовувати пояснювальноілюстративний метод із елементами частково-пошукового із використанням конкретно-індуктивної схеми введення нових знань, акцентуванням уваги на елементах історизму, на прийомах розумової діяльності (порівняння, аналогія, узагальнення, абстрагування, конкретизація), на одночасному формуванні способу прямої дії (в активному режимі) та оберненої дії (у фоновому режимі), метод проектів, реферативно-дослідницький квест.

У класі природничого профілю доцільно застосовувати навчальне спостереження, навчальний демонстраційний експеримент, дослідницьку лабораторну роботу, дослідницькі практикуми із вимірюваннями, дослідженнями та моделюванням тощо, тобто такі методи і прийоми, що актуалізують діяльність спостереження, знаходження закономірностей, висунення гіпотез.

Отже, методологія діатропічного підходу дає змогу структурувати зміст компетентнісно зорієнтованої методичної підготовки майбутнього вчителя математики профільної школи. Зміст компонується 3 методичних об'єктів і впорядковується для застосування діатропічних процедур задля виокремлення їхніх варіацій залежно від профілю навчання математики у школі.

Під методичним об'єктом М. Макарченко розуміє [3] інваріант математичного змісту шкільної освіти, цілісно представлений у повній або частковій методичній обробці. На нашу думку, до обсягу цього поняття доцільно віднести всі об'єкти, що утворюють предмет методики навчання математики як науки й навчальної дисципліни у ВНЗ. Отже, методичні об'єкти характеризують: 1) цілі навчання (на рівні окремих одиниць математичного змісту, їх систем, змістових ліній, тем, розділів тощо) та прийоми забезпечення прийняття учнями цілей вивчення навчального матеріалу курсу математики; 2) зміст навчання (елементи засвоєння шкільного курсу на рівні окремих понять, фактів, способів діяльності, їх систем у межах змістової лінії, програмової теми, розділу, класу тощо; 3) методи і прийоми, організаційні форми й засоби, спрямовані на сприймання та засвоєння учнями окремих одиниць математичного змісту (ОМЗ) (на рівні загальної методики, на рівні окремих методик), прийоми організації навчальної діяльності учнів та керування цією діяльністю; 4) різні форми контролю, оцінювання й корекції діяльності учнів у процесі навчання 
математики, що засвоюється на рівні стандарту, академічному та профільному рівнях, а також прийоми рефлексії та способи формування адекватної самооцінки учнів; 5) психолого-педагогічні основи процесу засвоєння учнями ОМЗ; 6) узагальнені способи й результати здійснення різних видів методичної діяльності (аналітикосинтетичної, діяльності з конструювання, прогнозування, моніторингу навчальних досягнень учнів тощо; 7) міжпредметні та внутрішньопредметні зв'язки шкільного курсу математики; 8) математичні, навчальні та методичні задачі, а також прийоми їх постановки й формулювання у процесі навчання математики, дії та відповідні їм операції під час розв'язування різних видів задач.

3-поміж видів методичних об'єктів, що є об'єктами дослідження й засвоєння у процесі методичної підготовки майбутнього вчителя математики профільної школи, додатково визначаємо такі:

1) зміст культурно-історичного й парадигмального аналізу етапів упровадження профільної диференціації в систему математичної освіти в Україні й у світі;

2) зміст основних положень концепції профільного навчання щодо сутності, мети і принципів організації профільного навчання, структури та форм організації допрофільної підготовки й профільного навчання;

3) логічні основи будови курсу математики, що вивчається на рівні стандарту, академічному і профільному рівнях та особливостей його змістових ліній;

4) змістовий аналіз загальноосвітньої та спеціалізуючої функцій курсу математики, який вивчається у класах різних профілів (на рівні стандарту, на академічному й профільному рівнях);

5) типи та види математичних моделей, що $\epsilon$ пріоритетними у процесі вивчення профільних дисциплін у класах відповідного профілю та у ВНЗ відповідного напряму;

6) система методів математики, що застосовуються для моделювання об'єктів, процесів і явищ, що вивчаються профільними дисциплінами;

7) система методів навчання профільних дисциплін та варіанти її врахування у процесі навчання математики в класах різних профілів;

8) прийоми структурування програмового матеріалу відповідно до лекційнопрактичної системи навчання математики у профільній школі та особливості побудови системи уроків відповідно до лекційно-практичної системи навчання математики у профільній школі: особливості підготовки та проведення підготовчих уроків, шкільної лекції, уроків-практикумів та семінарів, контрольно-залікових уроків у профільній школі;

9) цілі, зміст, методи і прийоми, організаційні форми проведення курсів за вибором у класах різних профілів;

10) цілі, зміст, методи, прийоми й організаційні форми науково-дослідної і проектної роботи учнів із математики у класах різних профілів.

Діатропічні процедури уможливлюють виявлення специфіки методичних об'єктів залежно від профілю навчання математики. Методичні об'єкти групуються, і в такий спосіб відбувається структурування змісту компетентнісно зорієнтованої методичної підготовки майбутнього вчителя математики профільної школи.

Зовнішнє структурування відображає варіативність методичних систем навчання математики (MCHM) у класах різних профілів, внутрішнє - інваріантні напрями для здійснення процедур діатропічного аналізу МСНМ у класах різних профілів.

Відповідно до зовнішнього структурування визначають такі змістові модулі: «Окремі аспекти теорії та практики профільної диференціації навчання математики у старшій школі», «Особливості навчання математики в класах суспільно- 
гуманітарного напряму (рівень стандарту)», «Особливості навчання математики у класах економічного профілю (суспільно-гуманітарний напрям, академічний рівень)», «Особливості навчання математики у класах природничого й технологічного профілів (рівень академічний)», «Особливості навчання математики у класах фізико-математичного профілю (профільний рівень)».

У внутрішній структурі кожного змістового модуля виокремлено когнітивнозмістовий комплекс (КЗК), який містить: 1) опис психологічних особливостей учнів, які обирають певний напрям (профіль) навчання; 2) предметно-математичну компетентнісну модель випускника класу певного напряму (профілю); 3) цільову модель навчання математики у класі певного напряму (профілю) і загальні особливості прийняття цілей учнями, які навчаються у класі певного напряму (профілю); 4) прийоми для мотивації до вивчення окремих тем у класах зазначеного напряму; 5) прикладні аспекти математичних понять і фактів, що входять до обсягу основних змістових ліній шкільного курсу математики, відповідно до профілю навчання; 6) зміст цільової, змістової, організаційно-управлінської, інструментальної, моніторингової моделей навчання окремих тем 3 алгебри й математичного аналізу та стереометрії у класах різних профілів; 7) характеристику вихідних позицій різних технологій навчання математики та особливостей їх застосування в навчанні математики учнів у класах різних профілів. Структура КЗК формує базис (головні, інваріантні стосовно профілів навчання напрями) для проведення процедур діатропічного аналізу різних компонентів методичних систем навчання математики у класах різних профілів.

Побудова методичної системи компетентнісно орієнтованої методичної підготовки майбутнього вчителя математики профільної школи з урахуванням методології діатропічного підходу уможливлює розв'язання завдання підготовки майбутнього фахівця до варіювання методичних систем навчання математики залежно від профілю навчання. Методологію діатропічного підходу необхідно втілювати в усіх компонентах методичної системи компетентнісно зорієнтованої методичної підготовки майбутнього вчителя математики профільної школи.

\section{Література}

1. Акуленко I. А. Компетентнісно орієнтована методична підготовка майбутнього вчителя математики профільної школи (теоретичний аспект) : [монографія] / І. А. Акуленко. - Черкаси : Видавець Чабаненко Ю., 2013. - 460 с. 2. Кузьмінський А. І. Наукові засади методичної підготовки майбутнього вчителя математики : [монографія] / А. І. Кузьмінський, Н. А. Тарасенкова, І. А. Акуленко. Черкаси : Вид. від. ЧНУ ім. Б. Хмельницького, 2009. - 320 с. 3. Макарченко М. Г. Модель контекстного обучения будущих учителей математики в процессе их методической подготовки : дисс. ... д-ра пед. наук : 13.00.02 «Теория и методика обучения и воспитания (математика)»/ Михаил Геннадиевич Макарченко; РГПУ им. А. И. Герцена. - СПб., 2009. - 402 с. $\quad$ 4. Малова И. Е. Непрерывная методическая подготовка учителя математики: автореф. дисс. на соискание ученой степени д-ра пед. наук: 13.00 .08 «Теория и методика профессионального образования» / Ирина Евгеньевна Малова. - Ярославль : ЯГПУ им. К. Д.Ушинского, 2007. - 42 c. 5. Морева О. В. Теоретические основы педагогического проектирования : монография / О. В. Морева; отв. ред. К. Н. Верховцев ; ТВВИКУ МО РФ. - Новосибирск : Изд-во СО РАН, 2006. - 270 с. 6. Моторіна В. Г. Професійна компетентність учителя математики профільної школи: [навч. посіб. для студ. природничо-матем. спец-тей пед. ВНЗ] / В. Г. Моторіна. - Х. : ХНПУ ім. Г. С. Сковороди, 2012. - 268 с. 7. Раков С. А. Формування математичних 
компетентностей учителя математики на основі дослідницького підходу у навчанні 3 використанням інформаційних технологій : автореф. дис. на здобуття наук. ступеня д-ра пед. наук : 13.00.02 «Теорія та методика навчання (математика)»/ Сергій Анатолійович Раков; НПУ ім. М. П. Драгоманова. - Х., 2005. - 44 с. 8. Семенець С. П. Методика навчання математики (підготовлено на основі концепції розвивальної освіти) : [навч. посібник] / С. П. Семенець. - Житомир : Вид-во ЖДУ ім. І. Франка, 2009. - 536 с. 9. Скафа Е. Средства формирования методической компетентности будущего учителя в системе эвристического обучения математике / Е. Скафа // Mathematics and Informatics /journal of educationresearch. - Vol. 56. - Number 3. $\quad$ Sofia, 2013. - C. 211-223. 10. Скворцова С. О. Динамічна модель формування методичних компетенцій у майбутніх учителів / С. О. Скворцова // Педагогіка формування творчої особистості у вищій і загальноосвітній школах: зб. наук. пр. / редкол. : Т. І. Сущенко (голов. ред.) та ін. - Запоріжжя, 2011. - Вип. 17 (70). - С. 177-183. 11. Стефанова Н. Л. Теоретические основы развития системы методической подготовки учителя математики в педагогическом вузе : дисс. ... д-ра пед. наук : 13.00 .02 «Теория и методика обучения и воспитания (математика)» / Наталия Леонидовна Стефанова. СПб., 1996. - 366 с. 12. Тарасенкова Н. А. До проблеми формування методичних компетентностей майбутнього вчителя математики профільної школи / Н. А. Тарасенкова, I. А. Акуленко // Розвиток педагогічних наук в Україні і Польщі на початку XX століття : зб. наук. пр. - Черкаси, 2011. - С. 273-279. 13. Чайковский Ю. В. Диатропика, эволюция и систематика: к юбилею Мейена : сб. ст. с приложением полного списка трудов С. В. Мейена, составленного И. А. Игнатьевым / Ю. В. Чайковский. - М. : Тов-во науч. изд. КМК, 2010. - 407 с.

УДК 796.01

Вадим Андріанов, Тарас Андріанов

\section{ПРОФЕСІЙНО-ПЕДАГОГІЧНА ПІДГОТОВКА МАЙБУТНЬОГО ВЧИТЕЛЯ ПОЧАТКОВИХ КЛАСІВ 3 ФІЗИЧНОЇ КУЛЬТУРИ}

Андріанов В. С., Андріанов Т. В. Професійно-педагогічна підготовка майбутнього вчителя початкових класів 3 фізичної культури.

У статті розглянуто питання формування професійно-прикладної фізичної підготовки майбутнього вчителя освітянської галузі, проаналізовано сутність професійно-прикладної фізичної підготовки та розглянуто її структуру в ситуаціях професійної діяльності особистості.

Ключові слова: професійно-прикладна фізична підготовка, структура, особистість, професійна діяльність.

Андрианов В. Е., Андрианов Т. В. Профессионально-педагогическая подготовка будущего учителя начальных классов по физической культуре.

В статье рассмотрен вопрос формирования профессионально-прикладной физической подготовки будущего учителя в сфере образования, проанализирована сущность профессионально-прикладной физической подготовки и рассмотрена его структура в ситуациях профессиональной деятельности личности.

Ключевые слова: профессионально-прикладная физическая подготовка, структура, личность, профессиональная деятельность. 